\title{
SISTEM INFORMASI DATA KECELAKAAN KERJA BERBASIS WEB PADA PT. ADIMULIA AGROLESTARI DI KUANTAN SINGINGI
}

\author{
Yulisman $^{1}$, Refni Wahyuni ${ }^{2}$, Bambang Kurniawan ${ }^{3}$ \\ ${ }^{1,3}$ Sistem Infomasi, STMIK Hang Tuah Pekanbaru \\ ${ }^{2}$ Teknik Informatika, STMIK Hang Tuah Pekanbaru \\ Jl. Mustafa Sari No. 5 Tangkerang Selatan, Pekanbaru - Riau \\ e-mail : yulisman@htp.ac.id ${ }^{1}$,refniabid@gmail.com ${ }^{2}$,ibenk.psht@gmail.com ${ }^{3}$
}

\begin{abstract}
ABSTRAK
Kejadian kecelakaan kerja yang terjadi pada setiap karyawan/pekerja di PT. Adimulia Agrolestari dilaporkan menggunakan form manual yaitu form dalam bentuk kertas dan untuk mendapatkan form tersebut karyawan harus mendatangi kantor area kerja terlebih dahulu, setelah itu form tersebut diserahkan kembali ke petugas P2K3 untuk diperiksa. Petugas P2K3 berkewajiban untuk menindaklanjuti kejadian kecelakaan kerja dengan melakukan investigasi dan perbaikan kejadian kecelakaan tersebut, selanjutnya laporan tersebut diberikan ke sekretaris $\mathrm{P} 2 \mathrm{~K} 3$, dan berdasarkan laporan dan form data kecelakaan kerja yang telah diisi oleh karyawan/pekerja tersebut sekretaris P2K3 harus menginput satu persatu ke aplikasi pengolah angka untuk rekapan laporan data kecelakaan kerja yang terjadi di perusahaan. Untuk mengatasi permasalahan tersebut maka diusulkan sistem informasi data kecelakaan kerja berbasis web, dengan menggunakan bahasa pemrograman PHP dan MySQL sebagai database, menggunakan model waterfall sebagai metode pembuatan sistem, dan diharapkan sistem informasi data kecelakaan kerja dapat dilakukan secara komputerisasi sehingga proses pengolahan data kecelakaan kerja menjadi lebih cepat dan akurat. Pemodelan dan perancangan sistem secara umum menggunakan UML. Dengan adanya aplikasi ini dapat membantu karyawan/pekerja untuk melaporkan kejadian kecelakaan kerja bisa langsung dari handphone/smartphone, dan sistem ini dapat membantu pekerjaan admin/sekretaris P2K3 menjadi lebih efektif dan efisien dalam pengolahan dan penyimpanan data kecelakaan kerja serta memudahkan membuat laporan kecelakaan kerja secara rinci dan lengkap.
\end{abstract}

Kata kunci : Data Kecelakaan Kerja, $M y S Q L$, Sistem Informasi, $P H P, U M L, W e b$

\begin{abstract}
Incidents of work accidents that occur in every employee/worker at PT. Adimulia Agrolestari reported using a manual form, namely a form in paper form and to get the form the employee had to go to the work area office first, after that the form was handed back to the P $2 K 3$ officer for inspection. The $P 2 K 3$ officer is obliged to follow up on work accidents by investigating and repairing the accident, then the report is given to the P2K3 secretary, and based on the report and work accident data form that has been filled out by the employee/worker, the P2K3 secretary must input one by one into the processing application. figures for the recapitulation of work accident data reports that occurred in the company. To overcome these problems, a web-based work accident data information system is proposed, using the PHP and MySQL programming languages as databases, using the waterfall model as a method of making the system, and it is hoped that the work accident data information system can be computerized so that the work accident data processing becomes faster and more accurate. Modeling and system design in general use UML. With this application, it can help employees/workers to report work accidents directly from their cellphones/smartphones, and this system can help the P2K3 admin/secretary work to be more effective and efficient in processing and storing work accident data and making it easier to make work accident reports accurately, detailed and complete.
\end{abstract}

Keywords : Work Accident Data, MySQL, Information Systems, PHP, UML, Web 
IN F O RM T I K A

Jurnal Informatika, Manajemen dan Komputer, Vol. 13, No. 2, Desember 2021

eISSN : 2580-3042

pISSN : 1979-0694

\section{PENDAHULUAN}

Pekerjaan merupakan kebutuhan pokok manusia yang wajib dipenuhi demi keberlangsungan hidupnya. Pekerjaan adalah suatu aktivitas yang penting bagi setiap individu menusia atau kegiatan yang dilakukan dengan iklas oleh setiap manusia untuk memperoleh pendapatan demi memenuhi kebutuhan hidup sehari-hari (Lestari et al., 2020). Hasil dari pekerjaan bisa memenuhi kebutuhkan pokok keluarga pekerja dalam jangka waktu tertentu. Setiap jenis pekerjaan mempunyai risiko yang diterima oleh pekerja, baik itu bekerja di lapangan (di luar ruangan) maupun bekerja di kantor (di dalam gedung/ruangan), serta berat atau ringannya pekerjaan tersebut. Risiko yang sering terjadi pada pekerja adalah kecelakaan kerja dalam bekerja. Kecelakaan kerja sering terjadi karena tidak benar dalam menerapkan standar K3 (Keselamatan dan Kesehatan Kerja) atau karena kelalaian pekerja itu sendiri (Nirtha et al., 2019).

Kecelakaan kerja merupakan salah satu kejadian yang tidak diharapkan oleh pekerja dan kejadianya pun sering terjadi secara tidak terduga (Fitriana \& Wahyuningsih, 2017). Kecelakaan kerja adalah kejadian yang terjadi yang menimpa pekerja dan berhubungan erat dengan pekerjaan, sehingga pekerja mengeluh kesakitan akibat penyakit yang diderita dan timbul saat bekerja atau kejadian yang terjadi ketika berangkat kerja dari rumah menuju ke tempat bekerja dan pulang ke rumah yang disertai luka, kelainan tubuh, cacat bahkan kematian (Putra, 2017). Pendapat peneliti kecelakaan kerja diartikan peristiwa yang tidak terduga disebabkan oleh tindakan tidak aman (unsafe action) yaitu aktifitas atau tindakan atau kebiasaan tidak aman dari pekerja yang mengakibatkan bahaya terhadap diri pekerja dan orang yang disekitarnya, serta kondisi tidak aman (unsafe condition) yakni melakukan aktifitas yang dapat membahayakan orang lain secara langsung (Masyudi \& Lizam, 2019).

PT. Adimulia Agrolestari adalah perusahaan perkebunanan sawit yang melakukan kegiatan operasional sejak tahun 1992. Memperoleh persetujuan pengusahaan perkebunan sawit pada saat itu adalah dari menteri pertanian melalui surat No. RC. 220/419/B/III/1992, tertanggal 4 Maret 1992. Pada proses awal pembangunan perkebunan kelapa sawit, PT. Adimulia Agrolestari mengajukan permohonan Hak Guna Usaha (HGU) melalui surat No. 65/BK-XI/1991 tertanggal 20 November 1991 dengan luas tanah yang diajukan adalah 6.500 Ha. PT. Adimulia Agrolestari adalah salah satu perusahaan yang mementingkan keselamatan karyawannya. Untuk itu setiap terjadinya kecelakaan kerja pada karyawannya selalu dicatat dengan tujuan untuk dapat mengetahui tingkat kejadian kecelakaan kerja sehingga dapat dilakukan perbaikan supaya kecelakaan kerja itu diharapkan tidak terjadi lagi. Berikut data jumlah karyawan/pekerja yang mengalami kecelakaan kerja pada periode januari-maret 2020 pada PT. Adimulia Agrolestari :

Tabel 1. Laporan Kecelakaan Kerja PT. Adimulia Agrolestari Januari-Maret 2020

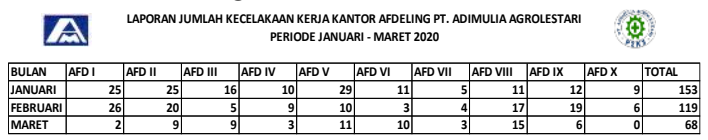

Keterangan: AFD adalah Afdeling atau devisi dan disebut juga satuan terkecil dalam mengelola perusahaan perkebunan sawit.

Berdasarkan tabel diatas dapat dilihat jumlah kecelakaan kerja karyawan setiap kantor area kerja di PT. Adimulia Agrolestari dengan jumlah bulan januari 153 orang, bulan Februari 119 orang dan bulan maret 68 orang. Dengan adanya pencatatan setiap kejadian kecelakaan kerja karyawan tersebut, PT. Adimulia Agrolestari dapat mengevaluasi segera dari tingkat kejadian kecelakaan kerja yang terjadi. Seperti melakukan penyuluhan dan pelatihan kepada setiap karyawannya dan untuk lebih memperhatikan keselamatan dan kesehatan dalam bekerja. Namun sistem data kecelakaan dan laporan kecelakaan kerja pada PT. Adimulia Agrolestari belum berjalan dengan baik dan masih menggunakan metode manual. Yang mana jika pekerja/karyawan mengalami kecelakaan kerja, pekerja/karyawan tersebut atau pelapor harus memberikan laporan kejadian tersebut dengan mengisi form kecelakaan yang sudah disediakan oleh perusahaan. Form kecelakaan tersebut telah disediakan di kantor area kerja masing-masing. Setelah mengisi laporan kecelakaan tersebut karyawan/pekerja menyerahkan kepada pengawas $\mathrm{P} 2 \mathrm{~K} 3$, selanjutnya pengawai P2K3 memeriksa dan mengisi laporan investigasi kecelakaan kerja. Kemudian dari data-data kecelakaan pekerja/ karyawan tersebut diarsipkan dan dimasukkan ke aplikasi pengolah angka dan huruf oleh sekretaris P2K3/Admin untuk merekap data kecelakaan kerja yang mana tujuannya adalah laporan data kecelakaan kerja 
IN F ORM A I K A

Jurnal Informatika, Manajemen dan Komputer, Vol. 13, No. 2, Desember 2021

elSSN : 2580-3042

pISSN : 1979-0694

karyawan setiap bulannya yang akan diberikan ke pimpinan. Selanjutnya dari laporan yang didapat itulah pimpinan melakukan evaluasi supaya segera melakukan perbaikan dari setiap kejadian kecelakaan kerja yang terjadi pada karyawannya.

Proses diatas terdapat kekurangan dan memakan waktu yang lama yaitu Sekretaris P2K3 harus satu persatu memasukkan laporan data-data kecelakaan kerja tersebut kedalam aplikasi pengolah angka dan huruf, serta admin juga mengalami kesulitan untuk membuat laporan bulanan secara lebih rinci dan untuk mengetahui tingkat kecelakaan yang terjadi. Selain itu untuk melaporkan setiap kejadian kecelakaan oleh pekerja/karyawan yang mengalami kecelakaan kerja, pekerja/karyawan harus mengambil form pelaporan kecelakaan kerja terlebih dahulu ke kantor area kerja masingmasing dan proses tersebut membutuhkan waktu yang cukup lama antara kejadian kecelakaan dan proses tindakan kecelakaan kerja oleh petugas P2K3 terhadap pekerja/karyawan yang mengalami kecelakaan kerja. Berdasarkan permasalahan-permasalahan yang ada tersebut dibutuhkan suatu sistem yang terkomputerisasi dan bisa diakses secara online oleh pekerja, yaitu sistem informasi data berbasis web yang dapat membantu Admin dalam melakukan pembuatan laporan serta penyimpanan data kecelakaan kerja dan untuk memudahkan dalam melaporkan kejadian kecelakaan kerja yang terjadi secara mudah dan cepat. Pada sistem informasi data kecelakaan kerja ini dapat diketahui jumlah korban kecelakaan kerja, tempat kejadian atau area kecelakaan kerja, dan akibat kecelakaan kerja. Dari data korban kecelakaan kerja dapat dilihat jumlah korban yang mengalami luka berat, luka ringan hingga korban meninggal. Dengan melihat data kecelakaan kerja dapat diketahui daerah area kerja yang sering terjadi kecelakaan dan dapat juga dilihat faktor apa yang mempengaruhi terjadinya kecelakaan kerja tersebut.

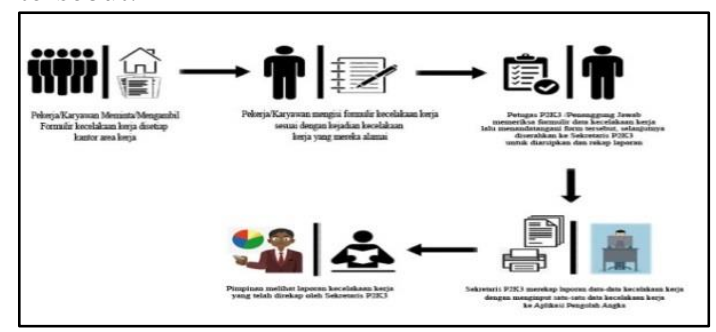

Gambar 1. Sistem Informasi Data Kecelakaan Kerja PT. Adimulia Agrolestari yang

(Sumber: Data Olahan) sedang berjalan

Sistem berbasis web memiliki keuntungan dengan file dan basis data (database) yang terpusat dan hanya memerlukan instalasi di server sehingga mudah dalam melakukan proses perawatan dan pemutakhiran (update). Selain itu penggunaan website mudah diakses dari jarak jauh (internet) dengan menggunakan browser, sehingga tidak harus melakukan instalasi terlebih dahulu pada semua perangkat keras yang ingin digunakan. Sistem pengolahan data berbasis web juga mudah untuk di kembangkan lagi dan aman dalam penggunaannya.

\section{METODOLOGI PENELITIAN}

Metodologi penelitian dalam membangun sistem informasi data kecelakaan kerja ini dengan mengiplementasi sebuah skema atau disebut juga model pembuatan/pengembangan sistem. Model yang digunakan adalah Waterfall Model. Model ini lebih mengedepankan tahapan yang berjenjang kebawah seperti air terjuan. Waterfall Model ini mewajibkan peneliti menyelesaikan tahapan demi tahapan, dengan arti peneliti tidak bisa melanjutkan ke tahapan berikut jika tahapan yang sedang dikerjakan belum selesai. Waterfall Model yang peneliti gunakan ini mengacu pada Waterfall Model yang disusun dan dikembangkan oleh Sommerville:

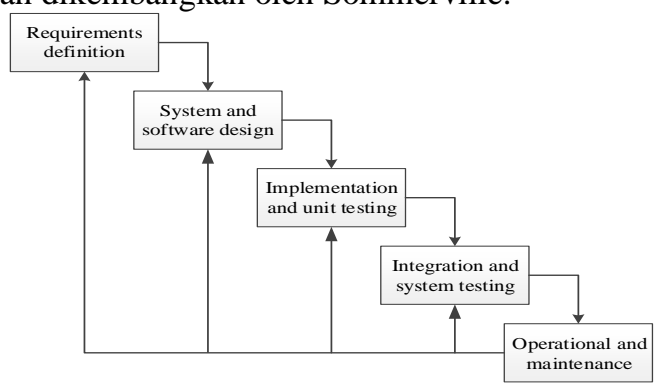

Gambar 2. Model Metode Waterfall

(Sommerville, 2011)

Berdasarkan skema dan tahapan model tersebut (waterfall) peneliti membangun sistem informasi data kecelakaan kerja sebagai berikut:

a. Requirements Definition

Tahap ini merupakan dimana peneliti untuk mendapat data yang terkait dengan permasalahan sistem pelaporan data kecelakaan kerja pada PT. Adimulia Agrolestari dan peneliti melakukan beberapa metode untuk mendapatkan data yang lebih lengkap, yakni dengan :

1. Observasi, yakni dimana peneliti dalam pengumpulan data melalui pengamatan 
IN F O RM T I K A

Jurnal Informatika, Manajemen dan Komputer, Vol. 13, No. 2, Desember 2021

eISSN : 2580-3042

pISSN : 1979-0694

secara langsung terhadap sistem pencatatan dan pengolahan data kecelakaan kerja di PT. Adimulia Agrolestari Kabupaten Kuantan Singingi.

2. Wawancara, tahapan pengumpulan data melalui tatap muka dan tanya jawab langsung dengan Sekretaris P2K3 yang berhubungan dengan penelitian. Misalnya, mengenai data-data yang dibutuhkan dalam proses pendataan untuk kebutuhan data yang diinginkan oleh penulis.

3. Studi pustaka, yakni mempelajari literatur, buku, jurnal, laporan skripsi terdahulu dan bahan-bahan yang berkaitan dengan materi dalam pembahasan laporan dan menulis data-data yang dibutuhkan dalam penulisan laporan.

\section{b. System and Software Design}

Setelah kebutuhan data dan informsi telah terkumpul dan lengkap, untuk selanjutnya dilakukan perancangan sistem dan perangkat lunak (System and Softaware Design). Perancangan sistem dan perangkat lunak dilakukan berdasarkan data dan informasi yang di dapat dari proses pendefinisian kebutuhan (Requirements Definition) sistem selesai dikerjakan, tahapan ini ada beberapa langkah yang harus dikerjakan peneliti:

1. Data Masukan (Input Data)

Terdiri dari data seluruh karyawan/ pegawai, data area bekerja, data departemen, data P2K3 dan data kecelakaan kerja.

2. Data Keluaran (Output Data)

Data keluaran yang terdiri dari Laporan Kecelakaan Kerja Karyawan, Laporan Jumlah Kecelakaan Kerja Setiap Departemen dan Laporan Jumlah Kecelakaan Kerja Setiap Area.

Setelah ditentukan data masukkan dan keluaran selanjutnya menentukan pengguna sistem, pengguna yang akan mendapatkan akses ke sistem secara langsung yang terdiri dari admin/sekretaris P2K3, karyawan/pekerja, pengawas P2K3 dan Pimpinan. Pengguna sistem telah ditentukan, langkah berikutnya peneliti melakukan pemodelan dan perancangan sistem secara umum yang merupakan gambaran bagaimana proses sistem berjalan secara keseluruhan nantinya ketika sistem telah siap digunakan. Untuk mempermudah proses perancangan dan pemodelan sistem peneliti menggunakan UML (Unified Modelling Language) yakni suatu metode pemodelan yang divisualisasikan dalam bahasa grafis dan sebagai sarana dalam perancangan dan pemodelan sistem perangkat lunak berorientasi objek (Fiqri et al., 2019). Pemodelan dan perancangan sistem yang di implementasikan adalah adalah Use Case Diagram, Class Diagram, dan Activity Diagram. Berikut hasil dari pemodelan dan perancangan sistem tersebut:

1. Use Case Diagram

Pemodelan dan perancangan dari UML yang pertama dibangun/dirancang untuk Sistem Informasi Data Kecelakaan Kerja Berbasis Web pada PT. Adimulia Agrolestari di Kuantan Singingi adalah Use Case Diagram. Use Case Diagram merupakan gambaran/visual yang menjelaskan komunikasi/interaksi antara sistem dengan pengguna (aktor) termasuk hak akses dan fitur yang didapat disistem oleh pengguna (aktor) (Sinaga, 2020). berikut Use Case Diagram yang telah dirancang:

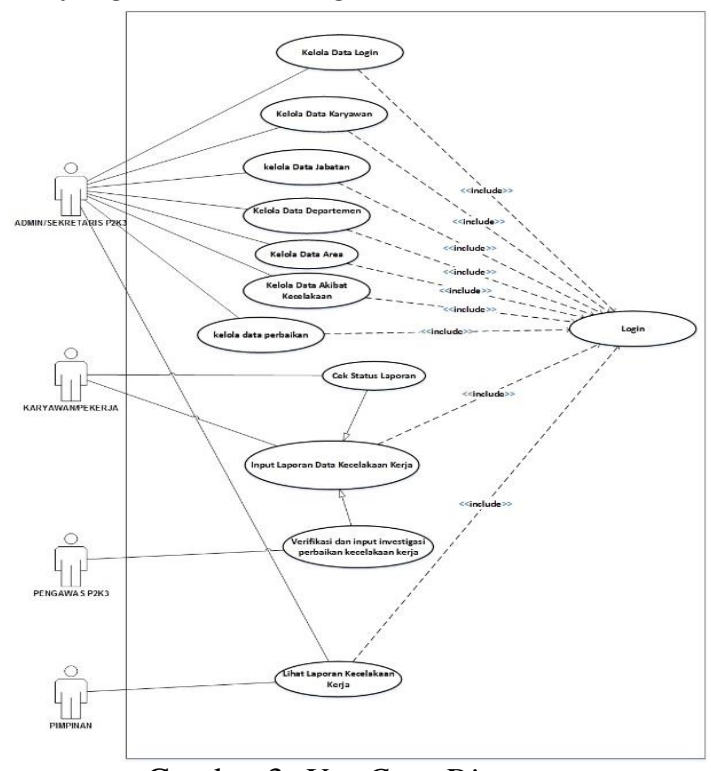

Gambar 3. Use Case Diagram

2. Activity Diagram

Pemodelan dan perancangan UML berikutnya adalah Activity Diagram yang menggambarkan sebagai analisis terhadap use case dengan menjelaskan tindakan (action) yang akan diambil beserta waktu saat pengguna (aktor) melakukan aktivitas di sistem yang dilengkapi oleh pesan yang diterima dan dikirim oleh objek (Ramadhona et al., 2014). Berikut beberapa Activity Diagram sistem informasi data Kecelakaan Kerja : 
IN F O R M A T I A

Jurnal Informatika, Manajemen dan Komputer, Vol. 13, No. 2, Desember 2021

eISSN : 2580-3042

pISSN : 1979-0694

a) Activity Diagram Login

Pada activity diagram login ini adalah aktivitas setiap aktor untuk masuk ke sistem dengan memasukkan nik dan password.

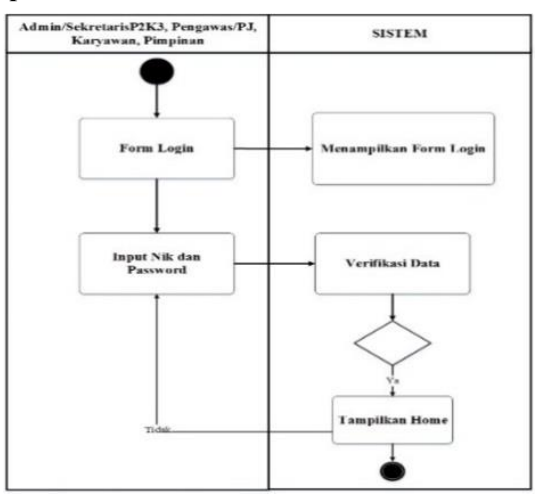

Gambar 4. Diagram Aktivitas Login Admin

b) Activity Diagram Mengelola Data Karyawan

Berikut adalah activity diagram mengelola data Karyawan ini merupakan aktivitas dari admin.

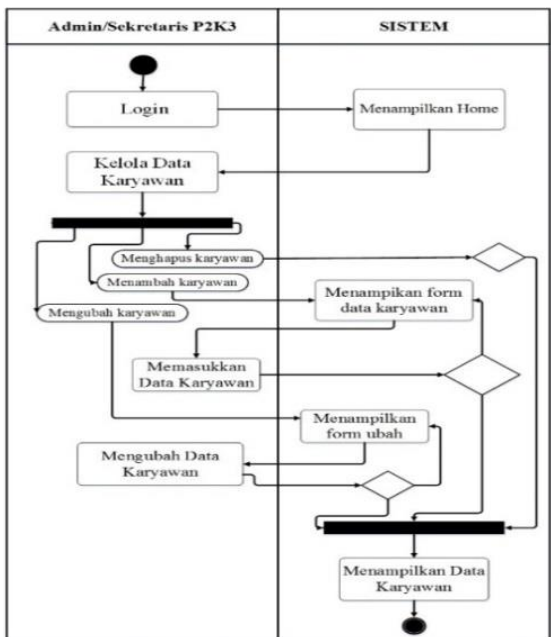

Gambar 5. Activity Diagram Mengelola Data Karyawan

Activity diagram mengelola data Karyawan di atas merupakan salah satu activity diagram untuk mengelola data, masih ada beberapa activity diagram yang berikaitan dengan mengelola Data, seperti activity diagram mengelola data jabatan, mengelola data departemen, mengelola data area, mengelola data akibat kecelakaan, dan mengelola data perbaikan. Aktivitas pengguna dan proses bisnis yang terjadi pada setiap Activity diagram tersebut sama, hanya namanya aktivitas yang berbeda.

c) Activity Diagram Mengelola Data Lapor Kecelakaan Kerja

Pada activity diagram dibawah ini adalah gambaran activity diagram mengelola data lapor kecelakaan kerja ini merupakan aktivitas selepas karyawan login.Karyawan memilih menu lapor kecelakaan kerja dan bisa menginput kejadian kecelakaan kerjanya, dan setiap karyawan dapat melihat laporan data kecelakaan kerja yang telah dilaporkannya.

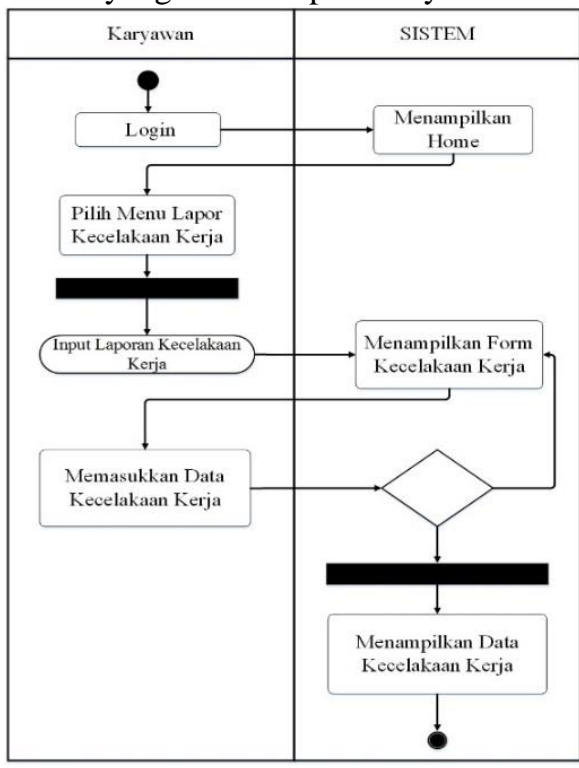

Gambar 6. Activity Diagram Mengelola Data Lapor Kecelakaan Kerja

d) Activity Diagram Verikfikasi data dan kelola data investigasi perbaikan Pada activity diagram verifikasi data dan kelola investigasi perbaikan kecelakaan kerja ini merupakan aktivitas selepas petugas p2k3 login. Petugas p2k3 memilih menu laporan kecelakaan kerja yang masuk lalu memeriksa laporan kecelakaan kerja dan verifikasi laporan tersebut. Selanjutnya petugas p2k3 melengkapi laporan kecelakaan tersebut dengan mengisi investigas kecelakaan kerja dan perbaikan dari kejadian kecelakaan tersebut. Setaip petugas p2k3 yang memverifikasi maka akan tercatat sebagai penanggung jawab untuk perbaikan kecelakaan kerja tersebut. Gambaran activity diagram dapat dilihat pada gambar di bawah ini. 
IN F ORM A I I A

Jurnal Informatika, Manajemen dan Komputer, Vol. 13, No. 2, Desember 2021

eISSN : 2580-3042

pISSN : 1979-0694

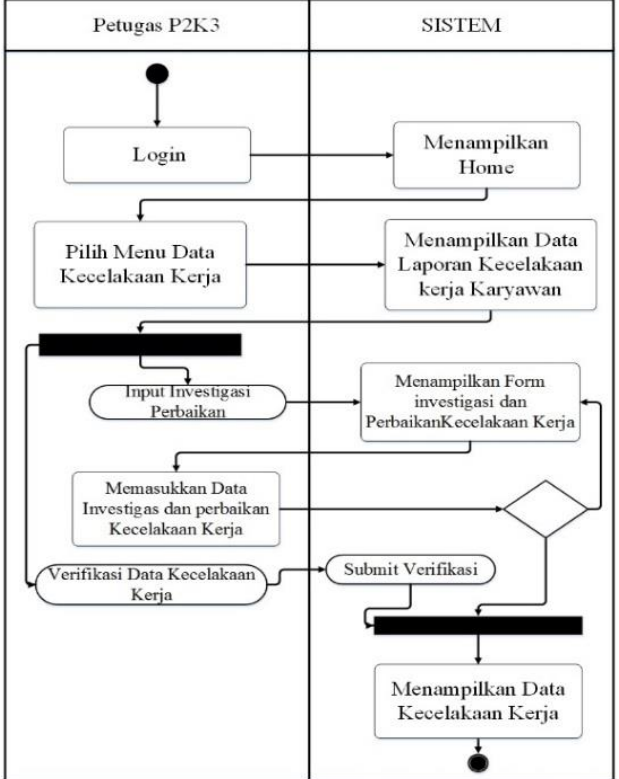

Gambar 7. Activity Diagram Verikfikasi data dan kelola data investigasi perbaikan

e) Activity Diagram Mengelola Laporan Data Kecelakaan Kerja

Pada activity diagram mengelola laporan data kecelakaan kerja ini merupakan aktivitas selepas Admin/Sekretaris P2k3 dan Pimpinan login. Aktor memilih menulaporan yang ingin dilihat dan actor juga dapat mencetak laporan tersebut. Gambaran activity diagram dapat dilihat pada gambar di bawah ini:

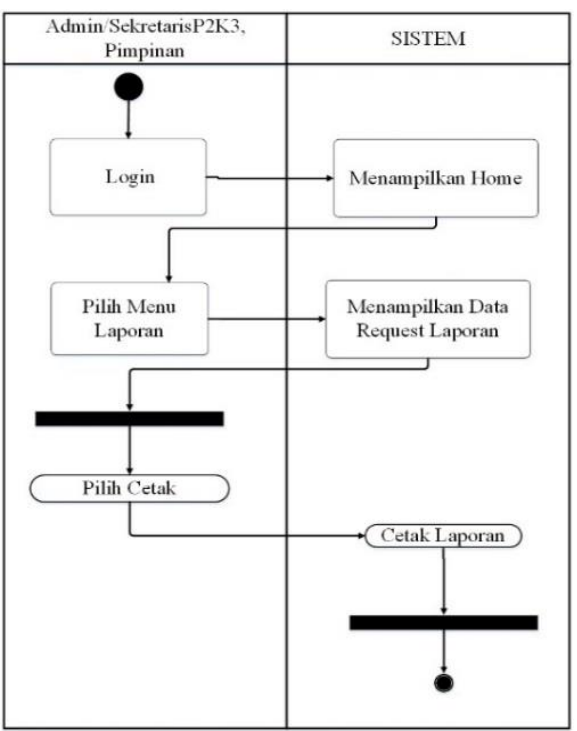

Gambar 8. Activity Diagram Mengelola Laporan Data Kecelakaan Kerja

\section{Class Diagram}

Class Diagram (Diagram Kelas) menggambarkan struktur sistem dari segi pendefinisian kelas-kelas yang ada di basis data akan dibuat untuk membangun sistem. Class diagram merupakan kelas yang tersusun digunakan untuk kebutuhan suatu sistem dan didefinisikan sebagai interaksi serta relasi antar kelas dalam sebuah sistem (Edy \& Mahmuman, 2020). Gambar class diagram dapat dilihat pada Gambar 9 berikut

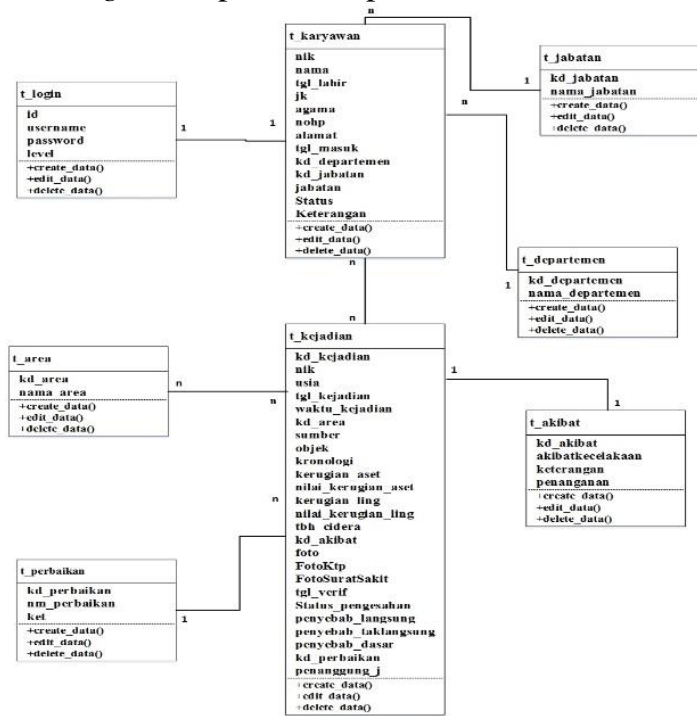

Gambar 9. Class Diagram Sistem Informasi Data Kecelakaan kerja

4. Basis data dan bahasa pemrograman

Setelah class diagram selesai di rancang, berikutnya perancangan dan pemodelan dilanjutkan membuat basis data (database). basis data (database) adalah sekumpulan file atau data yang bisa saling berinteraksi dan terhubung secara logis dan tersimpan di perangkat komputerisasi atau elektronik (Yanto, 2016). Basis data padat sistem informasi pengolahan data kecelakaan kerja ini diberi nama "aplikasi_kecelakaan_kerja" yang terdiri beberapa tabel, yakni tabel_login, tabel_karyawan, tabel_jabatan, tabel_area, tabel_kejadian, tabel_akibat, tabel_perbaikan, dan tabel_departemen.

Perancangan dan membangun basis data untuk sistem informasi pengolahan data kecelakaan kerja ini peneliti menggunakan $M y S Q L$ yang merupkan tool dari aplikasi $X A M P P$ dan aplikasi pendukung sebagai menampilkan basis data dan pengujian sistem menggunakan browser Chrome. Bahasa pemrograman yang peneliti gunakan adalah PHP (Hypertext Preprocessor) merupakan bahasa 
IN F ORM A I K A

Jurnal Informatika, Manajemen dan Komputer, Vol. 13, No. 2, Desember 2021

eISSN : 2580-3042

pISSN : 1979-0694

pemrograman yang dinamis berbasis web atau sebagai sebuah bahasa pemrograman yang server-side embedded script language, yakni semua sintaks dan perintah program yang dikoding dijalankan secara keseluruhan oleh server, atau bisa dengan HTML (Arifianto et al., 2016). Aplikasi Notepad ++ sebagai aplikasi pendukung dalam proses pembuatan sintaks dan perintah bahasa pemrograman.

Membuat dan perancangan tampilan antar muka merupakan tahapan berikut, merupakan tahapan yang tidak kalah pentingnya dalam membangun sebuah sistem. Proses perancangan dan membuat tampilan antar muka ini, peneliti sangat memperhatikan pada fungsi-fungsi, objekobjek serta fitur sistem yang mudah dipahami oleh pengguna. Dipahami dalam arti pengguna mudah dalam menjalankan dan mengoperasikan sistem, terutama bagi karyawan yang kurang memahami teknologi informasi. Peneliti merancang dan membuat tampilan antar muka (form) masukan (input design) dan tampilan antar muka (form) keluaran/laporan (output design) baik yang tidak maupun bisa dicetak (print out)

\section{c. Implementation and Unit Testing}

Implementation and Unit Testing (Impelmentasi dan pengujian unit) ini adalah tahapan ke tiga dari metode penelitian dengan menerapkan waterfall model. Tahapan dimulai dengan melakukan pengujian sistem per unit sistem yang telah selesai dibangun, pengujian ini bisa dilakukan ketika peneliti masih dalam proses penulisan sintaks dan perintah dari bahasa pemrograman. Pengujian per unit sistem bertujuan untuk mengetahui kesalahaan dan bug pada fungsi dan fitur sistem, jika ada terdapat kesalahan, peneliti bisa langsung melakukan perbaikan dan pengujian ini juga tidak akan mengganggu pada unit sistem lainnya yang telah selesai dibangun. Untuk unit pendukung sistem juga dilakukan pengujian seperti pengujian cetak laporan dengan menggunakan printer.

d. Integration and System Testing

Mengintegrasikan sistem (integrated system) merupakan proses penggabungan rangkaian sub sistem yang masih terpisah menjadi satu kesatuan sistem informasi pengolahan data kecelakaan kerja dan siap di implementasikan dan digunakan oleh pengguna. Untuk integrasi sistem ini ada beberapa langkah yang dilakukan peneliti, pertama adalah mengintegrasikan sistem dengan perangkat keras (hardware) pendukung seperti Server sistem, koneksi sistem ke internet (hosting), mengakses sistem dari klien (personal computer dan smartphone) dan koneksi printer serta komputer server dan klien. Ke dua adalah integrasi perangkat lunak (software), seperti aplikasi XAMPP, browser, aplikasi pdf, aplikasi pengolahan kata dan angka, dan yang ketiga melakukan sosialisasi dan pelatihan penggunaan aplikasi kepada pengguna, terutama kepada karyawan.

Tahapan integrasi sistem ini peneliti juga melakukan migrasi sistem. Migrasi sistem yang terapkan yakni dimana sistem lama tetap berjalan seiring dengan sistem yang baru juga dioperasikan dan digunakan. Untuk periode penerapan $100 \%$ sistem baru bisa digunakan, peneliti manargetkan selama enam dilakukan uji coba, dan setelah enam bulan sistem, uji coba dan penerpan sistem baru akan di evaluasi, jika belum mencapai $90 \%$ keatas, masa uji coba akan ditambah 3 bulan berikutnya. Setelah 3 bulan berlalu akan di evaluasi lagi jika belum mencapai $90 \%$ keatas akan dilakukan penambahan uji coba 3 bulan berikutnya sampai sistem berumur 1 tahun.

Langkah berikutnya pengujian sistem yang merupakan bagian dari proses integrasi sistem. Pengujian sistem merupakan proses untuk kekurangan sistem dari segi pengguna dan perangkat pendukung sistem lainnya, seperti hardware dan software yang telah dijelaskan di atas. Pengujian sistem harus melibatkan pengguna, minimal beberapa perwakilan pengguna yang terlibat langsung ke sistem. Pengujian sistem dilakukan tidak hanya sekedar mengetahui kesalahan pada sistem saja, tetapi perlu penerapan suatu metode pengujian sistem, disini peneliti menerapkan metode pengujian black box testing. Pengujian black box testing dengan memandang suatu sistem adalah sebuah kotak hitam dan oleh karena itu sistem hanya di eksekusi berdasarkan data uji dan memeriksa sistem secara fungsional (Nurzaman \& Setiawan, 2018). Berikut hasil pengujian black box pada sistem informasi pengolahan data kecelakaan kerja pada PT. PT. Adimulia Agrolestari : 
I N F ORM A I I A

Jurnal Informatika, Manajemen dan Komputer, Vol. 13, No. 2, Desember 2021 eISSN : 2580-3042

pISSN : 1979-0694

Tabel 2. Pengujian pada Login Admin

\begin{tabular}{|c|c|c|c|c|c|}
\hline No & $\begin{array}{c}\text { Skenario } \\
\text { Pengujian }\end{array}$ & $\begin{array}{l}\text { Text } \\
\text { Case }\end{array}$ & $\begin{array}{l}\text { Hasil Yang } \\
\text { Diharapkan }\end{array}$ & $\begin{array}{c}\text { Hasil } \\
\text { Pengujian }\end{array}$ & $\begin{array}{c}\text { Kesimp } \\
\text { ulan }\end{array}$ \\
\hline 1 & $\begin{array}{l}\text { Mengisikan } \\
\text { username } \\
\text { dan } \\
\text { password } \\
\text { yang tidak } \\
\text { terdaftar }\end{array}$ & $\begin{array}{l}\text { U: } \\
\text { admin } \\
P: 11\end{array}$ & $\begin{array}{l}\text { Sistem akan } \\
\text { menolak akses } \\
\text { dan } \\
\text { menampilkan } \\
\text { pesan } \\
\text { "username } \\
\text { dan password } \\
\text { tidak dikenal" }\end{array}$ & $\begin{array}{c}\text { Sesuai } \\
\text { harapan }\end{array}$ & Valid \\
\hline 2 & $\begin{array}{l}\text { Mengisikan } \\
\text { username } \\
\text { yang benar } \\
\text { dan } \\
\text { password } \\
\text { yang tidak } \\
\text { terdaftar }\end{array}$ & $\begin{array}{l}\text { U: } \\
\text { admin } \\
P: 11\end{array}$ & $\begin{array}{l}\text { Sistem akan } \\
\text { menolak akses } \\
\text { dan } \\
\text { menampilkan } \\
\text { pesan } \\
\text { "username } \\
\text { dan password } \\
\text { tidak dikenal" }\end{array}$ & $\begin{array}{c}\text { Sesuai } \\
\text { harapan }\end{array}$ & Valid \\
\hline 3 & $\begin{array}{l}\text { Mengisikan } \\
\text { username } \\
\text { yang tidak } \\
\text { benar dan } \\
\text { password } \\
\text { yang } \\
\text { terdaftar }\end{array}$ & $\begin{array}{l}\mathrm{U}: \\
\text { admin } \\
\mathrm{P}: 11\end{array}$ & $\begin{array}{l}\text { Sistem akan } \\
\text { menolak akses } \\
\text { dan } \\
\text { menampilkan } \\
\text { pesan } \\
\text { "username } \\
\text { dan password } \\
\text { tidak dikenal" }\end{array}$ & $\begin{array}{c}\text { Sesuai } \\
\text { harapan }\end{array}$ & Valid \\
\hline 4 & $\begin{array}{l}\text { Mengisikan } \\
\text { username } \\
\text { dan } \\
\text { password } \\
\text { dengan sql } \\
\text { injection }\end{array}$ & $\begin{array}{l}\text { U : ' } 1 \text { ', } \\
\text { or '1' } \\
\text { P : '1, } \\
\text { or '1' }\end{array}$ & $\begin{array}{l}\text { Sistem akan } \\
\text { menolak akses } \\
\text { dan } \\
\text { menampilkan } \\
\text { pesan "gagal } \\
\text { cek" }\end{array}$ & $\begin{array}{c}\text { Sesuai } \\
\text { harapan }\end{array}$ & Valid \\
\hline 5 & $\begin{array}{l}\text { Mengisikan } \\
\text { username } \\
\text { dan } \\
\text { password } \\
\text { yang } \\
\text { terdaftar }\end{array}$ & $\begin{array}{l}\text { U: } \\
\text { admin } \\
\text { P: } \\
\text { admin }\end{array}$ & $\begin{array}{l}\text { Sistem akan } \\
\text { menerima } \\
\text { akses dan } \\
\text { menampilkan } \\
\text { halaman } \\
\text { utamaadminist } \\
\text { rator }\end{array}$ & $\begin{array}{c}\text { Sesuai } \\
\text { harapan }\end{array}$ & Valid \\
\hline 6 & $\begin{array}{l}\text { Tambah, } \\
\text { edit, dan } \\
\text { hapus data } \\
\text { user }\end{array}$ & $\begin{array}{l}\text { U: } \\
\text { admin } \\
P: 11\end{array}$ & $\begin{array}{l}\text { System akan } \\
\text { menampilkan } \\
\text { aksi dari data } \\
\text { user ke } \\
\text { halaman } \\
\text { admin. }\end{array}$ & $\begin{array}{c}\text { Sesuai } \\
\text { harapan }\end{array}$ & Valid \\
\hline 7 & $\begin{array}{l}\text { Tambah, } \\
\text { edit, dan } \\
\text { hapus data } \\
\text { karyawan }\end{array}$ & $\begin{array}{l}\mathrm{U}: \\
\mathrm{admin} \\
\mathrm{P}: 11\end{array}$ & $\begin{array}{l}\text { System akan } \\
\text { menampilkan } \\
\text { aksi dari data } \\
\text { karyawan ke } \\
\text { halaman } \\
\text { admin. }\end{array}$ & $\begin{array}{c}\text { Sesuai } \\
\text { Harapan }\end{array}$ & Valid \\
\hline 8 & $\begin{array}{l}\text { Tambah, } \\
\text { edit, dan } \\
\text { hapus data } \\
\text { departemen }\end{array}$ & $\begin{array}{l}\text { U: } \\
\text { admin } \\
P: 11\end{array}$ & $\begin{array}{l}\text { System akan } \\
\text { menampilkan } \\
\text { aksi dari data } \\
\text { departemen ke } \\
\text { halaman } \\
\text { admin. } \\
\end{array}$ & $\begin{array}{c}\text { Sesuai } \\
\text { Harapan }\end{array}$ & Valid \\
\hline 9 & $\begin{array}{l}\text { Tambah, } \\
\text { edit, dan } \\
\text { hapus data } \\
\text { jabatan }\end{array}$ & $\begin{array}{l}\text { U: } \\
\text { admin } \\
P: 11\end{array}$ & $\begin{array}{l}\text { System akan } \\
\text { menampilkan } \\
\text { aksi dari data } \\
\text { jabatan ke } \\
\text { halaman } \\
\text { admin. }\end{array}$ & $\begin{array}{c}\text { Sesuai } \\
\text { Harapan }\end{array}$ & Valid \\
\hline 10 & $\begin{array}{l}\text { Tambah, } \\
\text { edit, dan } \\
\text { hapus data } \\
\text { area kerja }\end{array}$ & $\begin{array}{l}\text { U: } \\
\text { admin } \\
\text { P: } 11\end{array}$ & $\begin{array}{l}\text { System akan } \\
\text { menampilkan } \\
\text { aksi dari data } \\
\text { area kerja ke } \\
\text { halaman } \\
\text { admin }\end{array}$ & $\begin{array}{c}\text { Sesuai } \\
\text { Harapan }\end{array}$ & Valid \\
\hline 11 & $\begin{array}{l}\text { Tambah, } \\
\text { edit, dan } \\
\text { hapus data } \\
\text { perbaikan } \\
\text { kecelakaan }\end{array}$ & $\begin{array}{l}\text { U: } \\
\text { admin } \\
P: 11\end{array}$ & $\begin{array}{l}\text { System akan } \\
\text { menampilkan } \\
\text { aksi dari data } \\
\text { perbaikan } \\
\text { kecelakaan ke } \\
\text { halaman } \\
\text { admin } \\
\end{array}$ & $\begin{array}{c}\text { Sesuai } \\
\text { Harapan }\end{array}$ & Valid \\
\hline 12 & $\begin{array}{l}\text { Tambah, } \\
\text { edit, dan } \\
\text { hapus data } \\
\text { akibat } \\
\text { kecelakaan }\end{array}$ & $\begin{array}{l}\text { U: } \\
\text { admin } \\
P: 11\end{array}$ & $\begin{array}{l}\text { System akan } \\
\text { menampilkan } \\
\text { aksi dari data } \\
\text { akibat } \\
\text { kecelakaan ke } \\
\text { halaman } \\
\text { admin }\end{array}$ & $\begin{array}{c}\text { Sesuai } \\
\text { Harapan }\end{array}$ & Valid \\
\hline
\end{tabular}

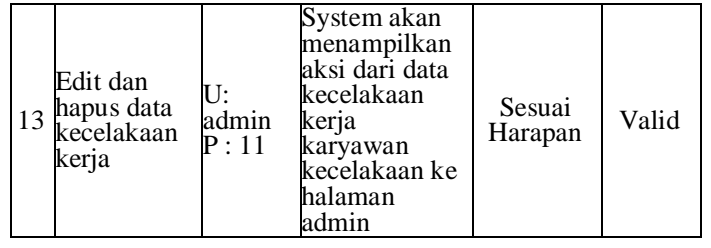

Tabel 3. Pengujian pada Login Karyawan

\begin{tabular}{|c|c|c|c|c|c|}
\hline No & $\begin{array}{c}\text { Skenario } \\
\text { Pengujian }\end{array}$ & Text Case & $\begin{array}{c}\text { Hasil Yang } \\
\text { Diharapkan }\end{array}$ & \begin{tabular}{|c|} 
Hasil \\
Pengujia \\
n
\end{tabular} & \begin{tabular}{|c} 
Kesi \\
mpul \\
an
\end{tabular} \\
\hline 1 & $\begin{array}{l}\text { Mengisikan } \\
\text { username } \\
\text { dan } \\
\text { password } \\
\text { yang tidak } \\
\text { terdaftar }\end{array}$ & $\begin{array}{l}\text { U: } \\
\text { karyawan } \\
\text { P: } 11\end{array}$ & $\begin{array}{l}\text { Sistem akan } \\
\text { menolak akses } \\
\text { dan } \\
\text { menampilkan } \\
\text { pesan } \\
\text { "username } \\
\text { dan password } \\
\text { tidak dikenal" }\end{array}$ & $\begin{array}{c}\text { Sesuai } \\
\text { harapan }\end{array}$ & Valid \\
\hline 2 & $\begin{array}{l}\text { Mengisikan } \\
\text { username } \\
\text { yang benar } \\
\text { dan } \\
\text { password } \\
\text { yang tidak } \\
\text { terdaftar }\end{array}$ & $\begin{array}{l}\text { U: } \\
\text { karyawan } \\
P: 11\end{array}$ & $\begin{array}{l}\text { Sistem akan } \\
\text { menolak akses } \\
\text { dan } \\
\text { menampilkan } \\
\text { pesan } \\
\text { "username } \\
\text { dan password } \\
\text { tidak dikenal" }\end{array}$ & $\begin{array}{l}\text { Sesuai } \\
\text { harapan }\end{array}$ & Valid \\
\hline 3 & $\begin{array}{l}\text { Mengisikan } \\
\text { username } \\
\text { yang tidak } \\
\text { benar dan } \\
\text { password } \\
\text { yang } \\
\text { terdaftar }\end{array}$ & $\begin{array}{l}\text { U : } \\
\text { karyawan } \\
\mathrm{P}: 11\end{array}$ & $\begin{array}{l}\text { Sistem akan } \\
\text { menolak akses } \\
\text { dan } \\
\text { menampilkan } \\
\text { pesan } \\
\text { "username } \\
\text { dan password } \\
\text { tidak dikenal" }\end{array}$ & $\begin{array}{l}\text { Sesuai } \\
\text { harapan }\end{array}$ & Valid \\
\hline 4 & $\begin{array}{l}\text { Mengisikan } \\
\text { username } \\
\text { dan } \\
\text { password } \\
\text { dengan sql } \\
\text { injection }\end{array}$ & $\begin{array}{l}\mathrm{U}: \text { : ‘1' or } \\
\text { P' } \\
\mathrm{P}: 1 \text { ' ' } 1 \text { ' or }\end{array}$ & $\begin{array}{l}\text { Sistem akan } \\
\text { menolak akses } \\
\text { dan } \\
\text { menampilkan } \\
\text { pesan "gagal } \\
\text { cek" }\end{array}$ & $\begin{array}{c}\text { Sesuai } \\
\text { harapan }\end{array}$ & Valid \\
\hline 5 & $\begin{array}{l}\text { Mengisikan } \\
\text { username } \\
\text { dan } \\
\text { password } \\
\text { yang } \\
\text { terdaftar }\end{array}$ & $\begin{array}{l}\text { U: } \\
\text { karyawan } \\
\text { P : } \\
\text { karyawan }\end{array}$ & $\begin{array}{l}\text { Sistem akan } \\
\text { menerima } \\
\text { akses dan } \\
\text { menampilkan } \\
\text { halaman } \\
\text { utama } \\
\text { karyawan } \\
\end{array}$ & $\begin{array}{l}\text { Sesuai } \\
\text { harapan }\end{array}$ & Valid \\
\hline 6 & $\begin{array}{l}\text { Tambah } \\
\text { data } \\
\text { kecelakaan } \\
\text { kerja }\end{array}$ & $\begin{array}{l}\text { U: } \\
\text { karyawan } \\
\text { P : } \\
\text { karyawan }\end{array}$ & $\begin{array}{l}\text { System akan } \\
\text { menampilkan } \\
\text { aksi dari data } \\
\text { kejadian } \\
\text { kecelakaan } \\
\text { kerja ke } \\
\text { halaman } \\
\text { karyawan } \\
\end{array}$ & $\begin{array}{c}\text { Sesuai } \\
\text { harapan }\end{array}$ & Valid \\
\hline 7 & $\begin{array}{l}\text { Lihat } \\
\text { Laporan } \\
\text { Data } \\
\text { Kecelakaan } \\
\text { kerja yang } \\
\text { diverifikasi }\end{array}$ & $\begin{array}{l}\text { U: } \\
\text { karyawan } \\
\text { P : } \\
\text { karyawan }\end{array}$ & $\begin{array}{l}\text { System akan } \\
\text { menampilkan } \\
\text { data kejadian } \\
\text { kecelakaan } \\
\text { kerja ke } \\
\text { halaman } \\
\text { karyawan } \\
\end{array}$ & $\begin{array}{l}\text { Sesuai } \\
\text { harapan }\end{array}$ & Valid \\
\hline
\end{tabular}

Tabel 4. Pengujian pada Login Petugas P2K3

\begin{tabular}{|c|l|l|l|c|c|}
\hline No & $\begin{array}{l}\text { Skenario } \\
\text { Pengujian }\end{array}$ & Text Case & $\begin{array}{c}\text { Hasil Yang } \\
\text { Diharapkan }\end{array}$ & $\begin{array}{c}\text { Hasil } \\
\text { Pengujia } \\
\text { n }\end{array}$ & $\begin{array}{c}\text { Kesi } \\
\text { mpul } \\
\text { an }\end{array}$ \\
\hline 1 & $\begin{array}{l}\text { Mengisikan } \\
\text { username } \\
\text { dan } \\
\text { password } \\
\text { yang tidak } \\
\text { terdaftar }\end{array}$ & $\begin{array}{l}\text { S: } \\
\text { petugas } \\
\text { menolak akses } \\
\text { dan }: 11 \\
\text { menampilkan } \\
\text { pesan } \\
\text { "username } \\
\text { dan password } \\
\text { tidak dikenal" }\end{array}$ & $\begin{array}{c}\text { Sesuai } \\
\text { harapan }\end{array}$ & Valid \\
\hline \multirow{2}{*}{2} & $\begin{array}{l}\text { Mengisikan } \\
\text { username } \\
\text { yang benar } \\
\text { dan }\end{array}$ & $\begin{array}{l}\mathrm{U} \text { : } \\
\text { petugas } \\
\mathrm{P}: 11\end{array}$ & $\begin{array}{l}\text { Sistem akan } \\
\text { menolak akses } \\
\text { dan } \\
\text { menampilkan }\end{array}$ & $\begin{array}{c}\text { Sesuai } \\
\text { harapan }\end{array}$ & Valid \\
\hline
\end{tabular}


INFORM TIK

Jurnal Informatika, Manajemen dan Komputer, Vol. 13, No. 2, Desember 2021

eISSN : 2580-3042

pISSN : 1979-0694

\begin{tabular}{|c|c|c|c|c|c|}
\hline & $\begin{array}{l}\text { password } \\
\text { yang tidak } \\
\text { terdaftar }\end{array}$ & & $\begin{array}{l}\text { pesan } \\
\text { "username } \\
\text { dan password, } \\
\text { tidak dikenal" }\end{array}$ & & \\
\hline 3 & $\begin{array}{l}\text { Mengisikan } \\
\text { username } \\
\text { yang tidak } \\
\text { benar dan } \\
\text { password } \\
\text { yang } \\
\text { terdaftar }\end{array}$ & $\begin{array}{l}\text { U: } \\
\text { petugas } \\
\text { P : } 11\end{array}$ & $\begin{array}{l}\text { Sistem akan } \\
\text { menolak akses } \\
\text { dan } \\
\text { menampilkan } \\
\text { pesan } \\
\text { "username } \\
\text { dan password" } \\
\text { tidak dikenal" }\end{array}$ & $\begin{array}{c}\text { Sesuai } \\
\text { harapan }\end{array}$ & Valid \\
\hline 4 & $\begin{array}{l}\text { Mengisikan } \\
\text { username } \\
\text { dan } \\
\text { password } \\
\text { dengan sql } \\
\text { injection }\end{array}$ & $\begin{array}{l}\mathrm{U}: \text { : ' } 1 \text { ' or } \\
11 \text {, ' } 1 \text { ' or } \\
\text { P, } 1 \text { ', }\end{array}$ & $\begin{array}{l}\text { Sistem akan } \\
\text { menolak akses } \\
\text { dan } \\
\text { menampilkan } \\
\text { pesan "gagal } \\
\text { cek" }\end{array}$ & $\begin{array}{c}\text { Sesuai } \\
\text { harapan }\end{array}$ & Valid \\
\hline 5 & $\begin{array}{l}\text { Mengisikan } \\
\text { username } \\
\text { dan } \\
\text { password } \\
\text { yang } \\
\text { terdaftar }\end{array}$ & $\begin{array}{l}\text { U: } \\
\text { petugas } \\
\text { P : } 11\end{array}$ & $\begin{array}{l}\text { Sistem akan } \\
\text { menerima } \\
\text { akses dan } \\
\text { menampilkan } \\
\text { halaman } \\
\text { utama petugas }\end{array}$ & $\begin{array}{c}\text { Sesuai } \\
\text { harapan }\end{array}$ & Valid \\
\hline 6 & $\begin{array}{l}\text { verifikasi } \\
\text { dan tolak } \\
\text { data } \\
\text { kecelakaan } \\
\text { kerja }\end{array}$ & $\begin{array}{l}\text { U: } \\
\text { petugas } \\
\text { P: } 11\end{array}$ & $\begin{array}{l}\text { System akan } \\
\text { menampilkan } \\
\text { aksi dari data } \\
\text { kejadian } \\
\text { kecelakaan } \\
\text { kerja ke } \\
\text { halaman } \\
\text { petugas }\end{array}$ & $\begin{array}{c}\text { Sesuai } \\
\text { harapan }\end{array}$ & Valid \\
\hline 7 & $\begin{array}{l}\text { Tambah } \\
\text { investigasi } \\
\text { perbaikan } \\
\text { kecelakaan } \\
\text { kerja }\end{array}$ & $\begin{array}{l}\text { U: } \\
\text { petugas } \\
\text { P: } 11\end{array}$ & $\begin{array}{l}\text { System akan } \\
\text { menampilkan } \\
\text { data } \\
\text { investigasi } \\
\text { perbaikan } \\
\text { kecelakaan } \\
\text { kerja ke } \\
\text { halaman } \\
\text { petugas }\end{array}$ & $\begin{array}{c}\text { Sesuai } \\
\text { harapan }\end{array}$ & Valid \\
\hline
\end{tabular}

e. Operation and Maintenance

Sistem telah diserah terimakan kepada pengguna dan bisa langsung implementasikan. Sementara itu sistem lama tetap berjalan paralel dengan sistem baru dan peneliti akan selalu mendampingi, baik dalam proses sosialisasi kepada pegawai/karyawan maupun dalam perawatan sistem dalam waktu 6 bulan penggunaan. Jika ada kesalahan atau bug pada sistem akan diperbaiki sesegera mungkin agar sistem tetap bisa dioperasikan sesuai dengan kebutuhan pengguna.

\section{HASIL DAN PEMBAHASAN}

Hasil merupakan sistem yang telah diuji dan telah selesai dibangun. Pengujian sistem dilakukan secara keseluruhan, baik pengujian perangkat keras maupun perangkat lunak pendukung sistem. Hasil ini berbanding dengan penelitian sebelumnya yang hanya memberikan informasi informasi terhadap kecelakaan yang sering terjadi di perusahaan, pengguna mengetahui tindak perbaikan yang dilakukan oleh Penanggung Jawab, serta laporan bulanan untuk tingkat kecelakaan yang terjadi setiap harinya (Merliana, 2015), sedangkan untuk hasil penelitian ini kita dapat melihat tampilan dari sistem sebagai berikut:

a. Tampilan login pengguna

Tampilan awal sistem adalah Tmapilan/Form Login pengguna sistem, dimana semua pengguna bisa mengakses form ini untuk masuk ke sistem, berikut tampilannya:

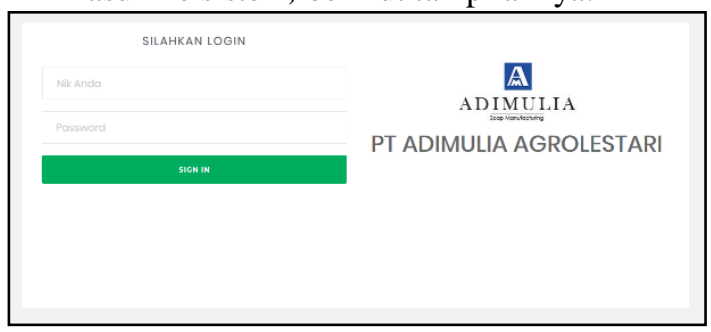

Gambar 10. Tampilan Form Login Pengguna

b. Tampilan Dashboard Admin/Sekretaris P2K3 Halaman utama/Dashboard merupakan tampilan yang muncul setelah pengguna login ke sistem. Hasil Tampilan dashboard dapat dilihat pada gambar dibawah ini:

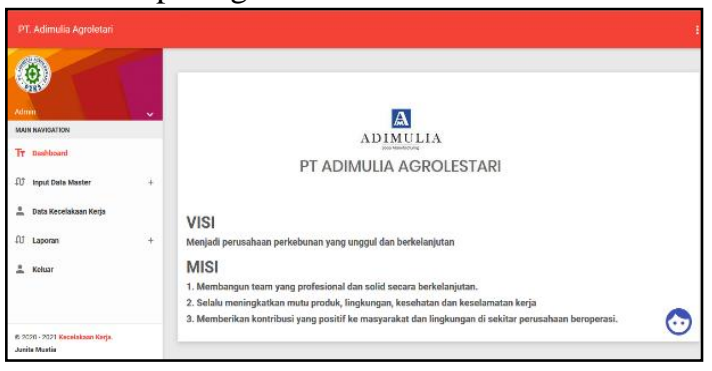

Gambar 11. Tampilan Form Dashboard Admin/Sekretaris P2K3

1. Menu/Tampilan Data Pengguna Menu/tampilan data pengguna ini merupakan daftar pengguna yang bisa login ke sistem. Daftar pengguna bisa input, edit dan delete oleh admin/sekretaris P2K3. Hasil menu/tampilan data pengguna dapat dilihat pada gambar 12 berikut:

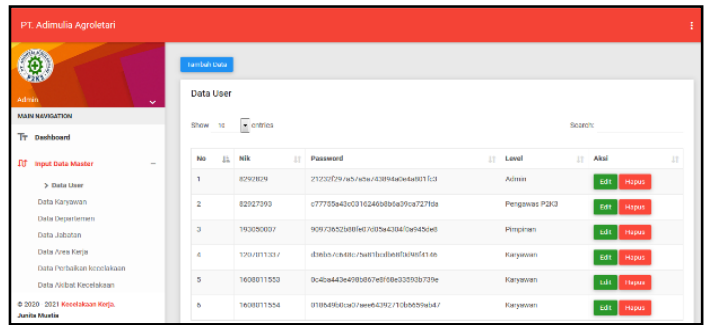

Gambar 12. Tampilan Form Daftar Pengguna

2. Menu/Tampilan Data karyawan Menu/Tampilan ini merupkan daftar data karyawan dan juga bisa mengaksis sistem. 
I N F O R M A T I K

Jurnal Informatika, Manajemen dan Komputer, Vol. 13, No. 2, Desember 2021

elSSN : $2580-3042$

pISSN : 1979-0694

Untuk admin bisa input, edit dan delete data karyawan dan berikut tampilannya:

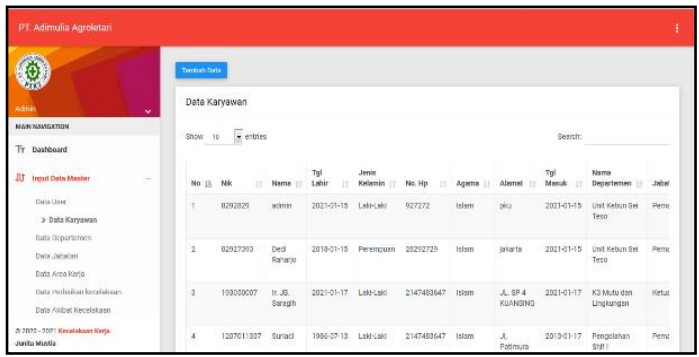

Gambar 12. Tampilan Form Data Karyawan

3. Menu/Tampilan Data Departemen Berikut adalah Menu/tampilan data departemen yang merupakan daftar data departemen yang ada di PT. Adimulia Agrolestari. Admin bisa men-input, edit dan delete data departemen.

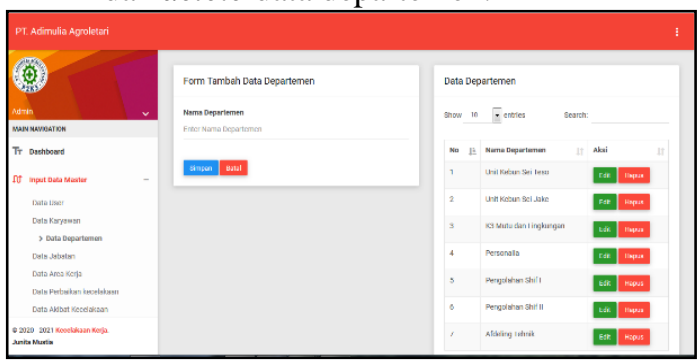

Gambar 13. Tampilan Form Data Departemen

4. Menu/Tampilan Data Jabatan

Menu data jabatan ini merupakan menu untuk menambahkan dan menampilkan data jabatan. Di halaman ini admin bisa input, edit dan delete. Hasil tampilan menu jabatan dapat dilihat pada gambar 14. dibawah ini:

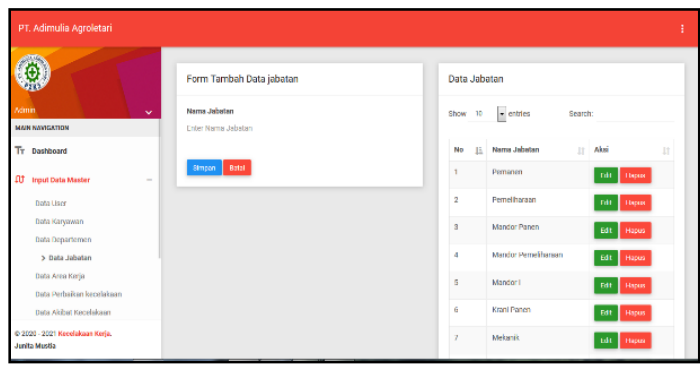

Gambar 14. Tampilan Form Data Departemen

5. Menu/Tampilan Data Area Kerja Gambar berikut adalah menu/tampilan untuk menambahkan dan menampilkan data area kerja karyawan. Di menu/tampilan ini admin bisa input, edit dan delete area kerja karyawan:

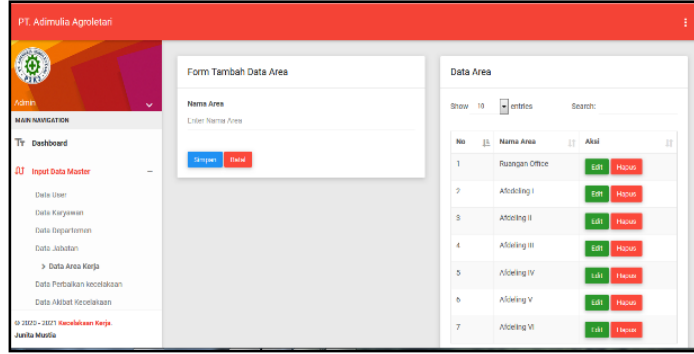

Gambar 15. Tampilan Form Data Area Kerja

6. Menu/Tampilan Data Perbaikan Kecelakaan Kerja

Pada menu/tampilan ini ditampilkan data perbaikan kecelakaan kerja dan data tersebut bisa di input, edit dan delete oleh admin. Berikut menu/tampilan perbaikan kecelakaan kerja:

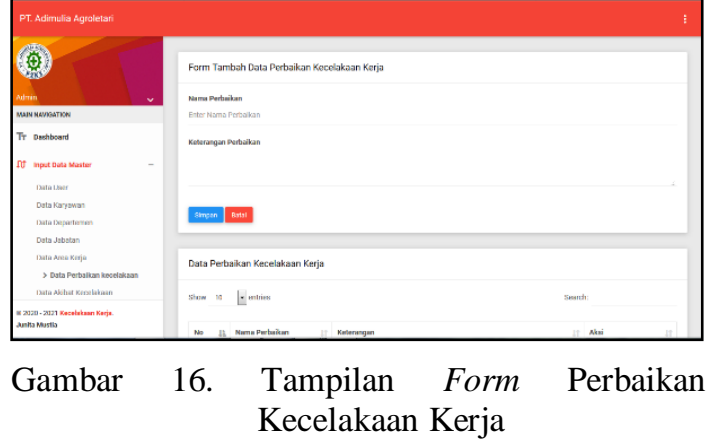

7. Menu/Tampilan Data Akibat Kecelakaan Kerja

Menu/tampilan akibat kecelakaan kerja ini merupakan menu/tampilan untuk menampilkan data akibat kecelakaan kerja. Aktivitas yang bisa dilakuakn admin adalah men-input, edit dan delete data akibat kecelakaan kerja. Gambar berikut adalah tampilan menu akibat kecelakaan kerja.

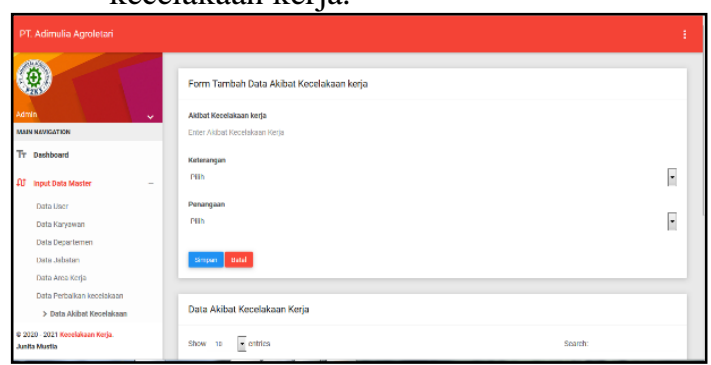

Gambar 17. Tampilan Form Akibat Kecelakaan Kerja 
IN F ORMA TIK A

Jurnal Informatika, Manajemen dan Komputer, Vol. 13, No. 2, Desember 2021

eISSN : 2580-3042

pISSN : 1979-0694

8. Menu/Tampilan Data Kecelakaan Kerja Menu data kecelakaan kerja ini merupakan menu untuk melihat data kecelakaan kerja secara keseluruhan dan admin bisa meng-edit dan delete data. Berikut tampilan form data kecelakaan pada gambar dibawah ini:

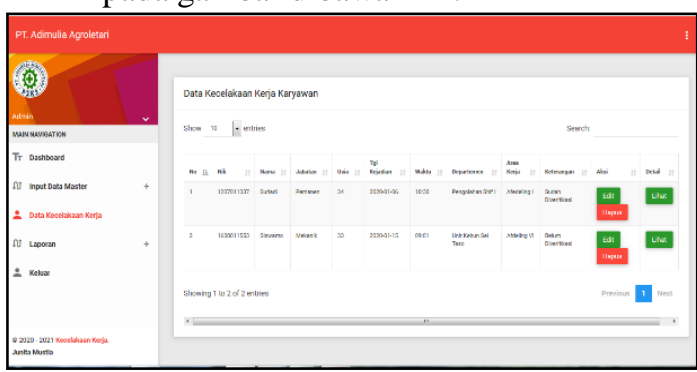

Gambar 18. Tampilan Form Data Kecelakaan Kerja

Jika ingin melihat tampilan data secara detail, admin bisa mengklik tombol lihat dan akan tampil gambar berikut:

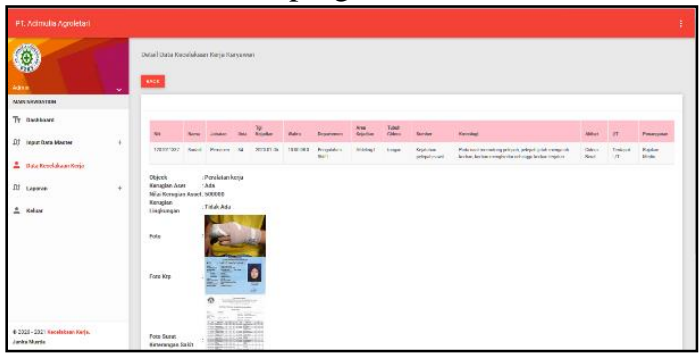

Gambar 19. Tampilan Form Data Kecelakaan Kerja

9. Menu Laporan dan Grafik

Menu laporan yang ada di admin merupakan laporan data kecelakaan kerja yang telah diverifikasi dan dilakukan perbaikan bagian investigasi kecelakaan kerja. Admin juga bisa menampilkan grafik data kecelakaan kerja, berikut tampilan form menu laporan dan grafik:

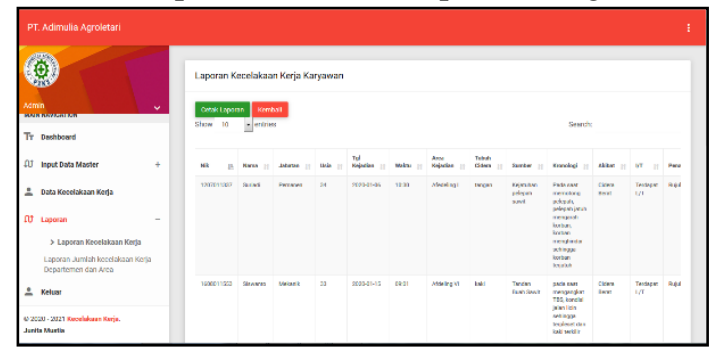

Gambar 20. Tampilan Form Laporan Data Kecelakaan Kerja
Berikut grafik laporan data kecelakaan kerja:

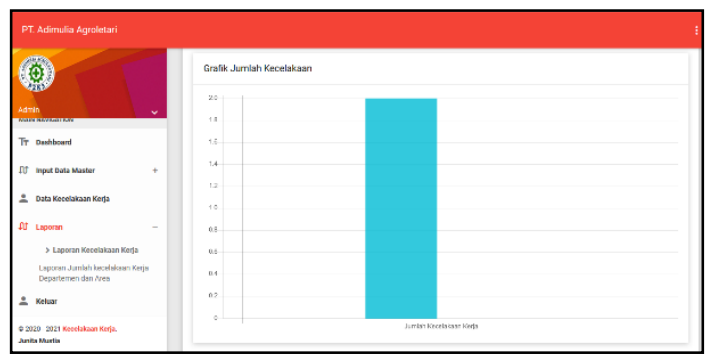

Gambar 21. Tampilan Form Grafik Laporan Data Kecelakaan Kerja

c. Tampilan Form Dashboard

Karyawan/Pekerja

Tampilan berikut merupakan dashboard setelah karyawan/pekerja login ke sistem informasi pengolahan data kecelakaan kerja menggunakan NIK karyawan/pekerja dan ada beberapa menu yang didapat karyawan/pekerja yakni untuk melaporkan kecelakaan kerja dan petunjuk pengisian form laporan kecelakaan kerja, dan ada tombol detail jika karyawan/pekerja ingin melihat detail laporan kecelakaan kerja yang telah dilaporkan. berikut dashboard karyawan/pekerja dapat dilihat pada gambar dibawah:

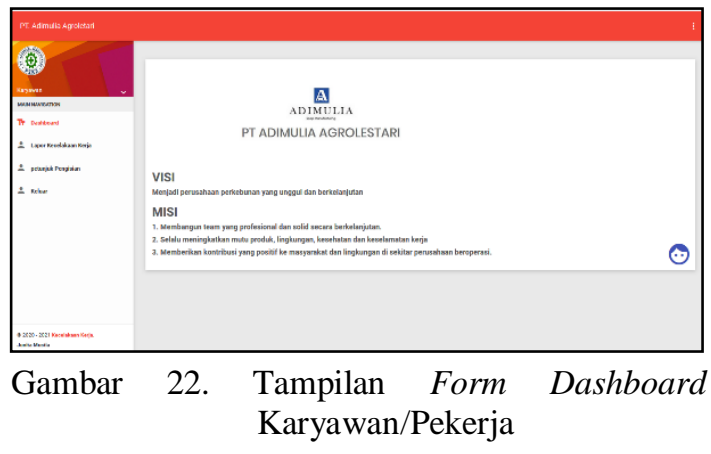

d. Tampilan Form Dashboard Pengawas P2K3 Gambar dibawah ini merupakan dashboard dari hak akses pengawas P2K3 login ke sistem informasi data kecelakaan kerja menggunakan username dan password yang telah terdaftar dan ada beberapa menu yang bisa dimanfaatkan oleh Pengawas P2K3 diantaranya data kecelakaan kerja dan Pengawas P2K3 bisa melihat data kecelakaan kerja secara detail. 
IN F O RM T I K A

Jurnal Informatika, Manajemen dan Komputer, Vol. 13, No. 2, Desember 2021

eISSN : 2580-3042

pISSN : 1979-0694

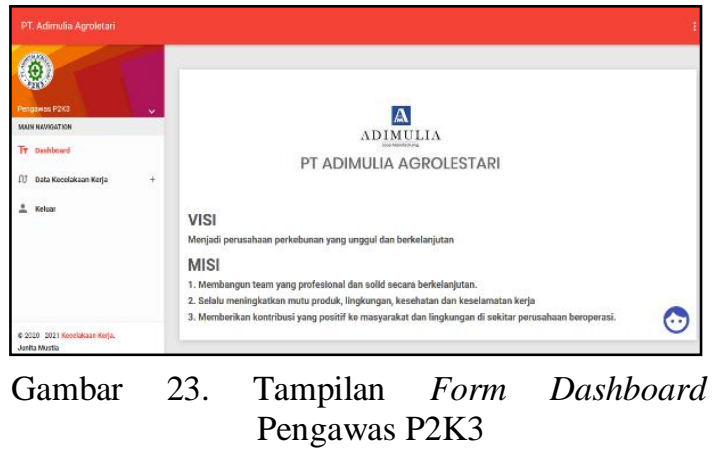

kesimpulan dimana sistem informasi data kecelakaan kerja berbasis web pada PT. Adimulia Agrolestari ini dapat membantu karyawan/pekerja dalam melaporkan kejadian kecelakaan kerja hanya dengan mengakses sistem dari handphone/smartphone.

Sistem informasi data kecelakaan kerja berbasis web pada PT. Adimulia Agrolestari dapat membantu pekerjaan admin/sekretaris P2K3 menjadi lebih efektif dan efisien dalam pengolahan data dan penyimpanan data kecelakaan kerja serta sistem memudahkan membuat laporan kecelakaan kerja secara rinci dan lengkap. Sistem juga berbasis web mobile, sehingga aplikasi ini dapat dibuka melalui Personal Computer/Laptop maupun smartphone, karena aplikasi web ini bersifat responsive.

Berdasarkan penilaian dari perwakilan pengguna ketika sistem didemokan dengan mengisi kuesioner usability sistem memperoleh poin 40,4 dengan kategori sistem Baik Sekali. Adapun kriteria sistem yang dinilai oleh pengguna adalah: sistem mudah digunakan, sistem sesuai kebutuhan pengguna, tampilan sistem menarik dan friendly, sistem lengkap baik dari segi fitur dan modul.

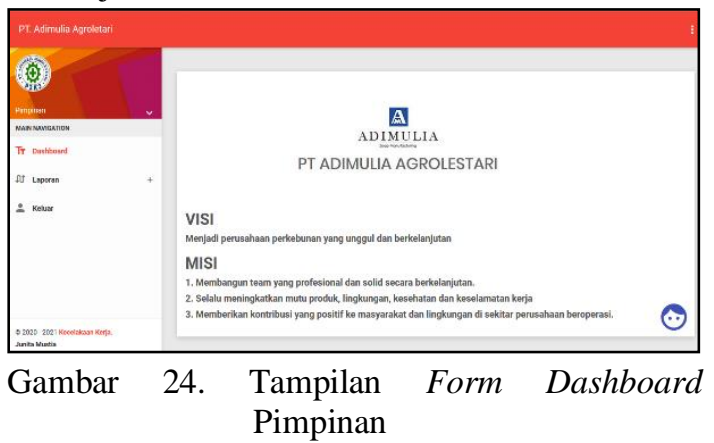

f. Tampilan Cetak Laporan

Berikut adalah salah satu tampilan cetak laporan dari data kecelakaan kerja:

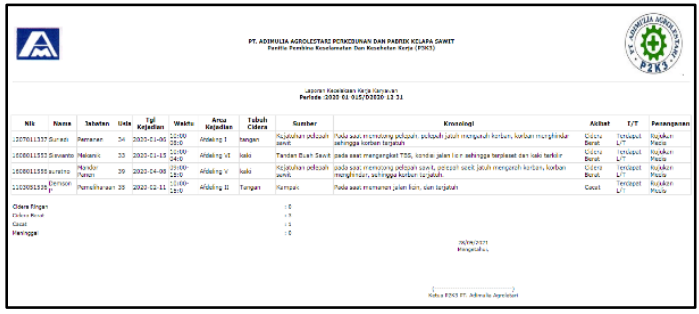

Gambar 25. Tampilan Hasil Cetak Laporan

\section{KESIMPULAN}

Berdasarakan uraian dari hasil dan pembahasan penelitian dapat diperoleh

\section{REFERENSI}

Arifianto, D. A., Kusuma, G. P., \& Prasetyo, H. N. (2016). Aplikasi Pencatatan dan Pelaporan Kasus Kecelakaan Lalu Lintas pada Direktorat Lalu Lintas Polrestabes Bandung. EProceedings of Applied Science, 2(1), 190-196. https://openlibrarypublications.telkomunive rsity.ac.id/index.php/appliedscience/article/ view/4060/3835

Edy, N., \& Mahmuman. (2020). Sistem Pelaporan Kecelakaan Lalulintas Dengan Pendekanan Geographics Information System. Jurnal Ilmiah Sains Dan Teknologi, 4(2), 151-161. http://ejournal.lppm-

unbaja.ac.id/index.php/saintek/article/view/ 1014

Fiqri, A. N., Anggraeni, S., Zen, N., \& Azmmi, R. A. (2019). Aplikasi Seblak "Seputar Berita Kecelakaan" Berbasis Android. Jurnal Techno Nusa Mandiri, 16(2), 139146.

https://doi.org/10.33480/techno.v16i2.648 
IN F O R M A T I A

Jurnal Informatika, Manajemen dan Komputer, Vol. 13, No. 2, Desember 2021

eISSN : 2580-3042

pISSN : 1979-0694

Fitriana, L., \& Wahyuningsih, A. S. (2017). Penerapan Sistem Manajemen Kesehatan dan Keselamatan Kerja (SMK3) di PT. Ahmadaris. HIGEIA : Journal Of Public Health Research And Development, 1(1), 29-35.

https://journal.unnes.ac.id/sju/index.php/hi geia/article/view/14004/7645

Lestari, I. D., Samsugi, S., \& Abidin, Z. (2020). Rancang Bangun Sistem Informasi Pekerjaan Part Time Berbasis Mobile Di Wilayah Bandar Lampung. TELEFORTECH: Journal of Telematics and Information Technology, 1(1), 18-21. https://doi.org/10.33365/tft.v1i1.649

Masyudi, \& Lizam, T. C. (2019). Analisis Risiko Kecelakaan Kerja pada Pekerja Pabrik Pengolahan Kelapa Sawit Lembah Bhakti Kabupaten Aceh Singkil. 2(1), 66-74. http://ejournal.helvetia.ac.id/index.php/jkg/ article/view/4438

Merliana, I. (2015). Sistem Informasi Kecelakaan (Nearmiss) Karyawan pada PT. Tirta Investama Cabang Airmadidi. Politeknik Negeri Manado.

Nirtha, R. I., Firmansyah, M., \& Prahastini, H. (2019). Analisis Pengaruh Penerapan Keselamatan Dan Kesehatan Kerja (K3) Terhadap Kinerja Karyawan Di Perkebunan Kelapa Sawit Pt. Hasnur Citra Terpadu. Jukung (Jurnal Teknik Lingkungan), $\quad 5(1), \quad 75-85$. https://doi.org/10.20527/jukung.v5i1.6203

Nurzaman, Z., \& Setiawan, E. B. (2018). Implementasi Teknologi Geotagging pada Aplikasi Pertolongan Kecelakaan Lalu Lintas. Jurnal Ilmu Komputer Dan Informatika (KOMPUTA), 7(1), 35-42. http://komputa.if.unikom.ac.id/_s/data/jurn al/volume-7/05.komputa-7.1-geotagingzamzam-eko.pdf/pdf/05.komputa-7.1geotaging-zamzam-eko.pdf

Putra, D. P. (2017). Penerapan Inspeksi Keselamatan Dan Kesehatan Kerja Sebagai Upaya Pencegahan Kecelakaan Kerja. Higeia Journal of Public Health Research and Development, 1(3), 84-94. https://journal.unnes.ac.id/sju/index.php/hi geia/article/view/15976

Ramadhona, Rispianda, \& Wahyuning, C. S. (2014). Rancangan Sistem Informasi Investigasi Kecelakaan Pada Knkt (Komite Nasional Keselamatan Transportasi). Reka Integra, 2(3), 174-186. https://ejurnal.itenas.ac.id/index.php/rekain tegra/article/view/550/775

Sinaga, T. H. (2020). Analisis dan Desain Sistem Pencatatan Data Manifes Kapal Penyeberangan Menggunakan Metode PIECES dan UML. Riau Journal Of Computer Science, 06(01), 23-33. https://doi.org/10.30606/rjocs.v6i1.1969

Sommerville, I. (2011). Software Engineering (9th editio). Pearson Education.

Yanto, R. (2016). Manajemen Basis Data Menggunakan MySQL. Deepublish. 